Submitted, accepted and published by Taylor \& Francis, Ethology, Ecology \&Evolution, 24(3): 294-300 (2012)

\title{
Historical books in ethology: sexual purpose used to explain two ancient docu- mentations of infanticide by males
}

We have recently discovered some interesting ancient (450 B.C. and 1644 A.D.) non-scientific documents that refer to a current controversial topic: infanticide by male mammals. Our aim in this forum article is to highlight the potential role of traditional observations in ethology. Here we describe the ongoing controversy among anthropologists and ethologists about the reasons for infanticide by males, and we show two historical references on this subject and their interpretation.

\section{A role of historical non-scientific knowledge in ethology}

Historical, traditional knowledge is being slowly incorporated into many branches of natural sciences. The best example is perhaps the acceptance by a new scientific discipline, ethno-botany, of traditional approaches for the identification and use of medicinal plants (e.g. COTTON 1996). Also, the importance of local, non-scientific knowledge has been recognised in resource management; for instance in fisheries (e.g. Johannes et al. 2000), use of pasture in semi-arid lands (e.g. NiAmir-Fuller 1998), management of forest ecosystems with a high diversity of tree ages and species (e.g. PinKERTON 1998) and in biodiversity conservation generally (e.g. REDFORD \& STEARMAN 1993).

However, despite the call for an ethno-ethology (e.g. LESTEL et al. 2006), traditional references to the behaviour of animals have been more closely associated with the study of folklore, myths and other cultural fields than with behavioural sciences. One of the main reasons for that is probably the tendency for humans to empathise with animals and analyse and describe their behaviour in human terms, thus associating different behavioural patterns with moral qualities, such as virtues and vices (BUENoSÁNCHEZ 1978). Frequently, this moves people to complement accurate observations with inaccurate data and prejudiced interpretations, making it difficult to separate facts from fiction. Macedonian herders, for example, accurately observed that bears (Ursus arctos) usually only kill one sheep and eat it, whereas wolves (Canis lupus) frequently kill multiple sheep in each attack. However, from this correctly identified behaviour they concluded inaccurately that wolves enjoy killing and even that "the wolf will kill 99 sheep and die at the hundredth” (LESCUREux \& LinNell 2010).

This mixture of relevant facts and wrong conclusions does appear in many old sources dealing with animal behaviour. For instance, ornithologists currently know that common swifts (Apus apus) are remarkable flyers that use a perch only to breed, and that they frequently fly up to $3000 \mathrm{~m}$ in altitude during the night, in more-or-less complete darkness (LACK 1956; BÄCKMAN \& ALERSTAM 2002). It is noteworthy that in 1630, more than three centuries ago, a Spanish Jesuit named Juan Eusebio Nieremberg y Otin (quoted in BuENO-SÁNCHEZ 1978) described this characteristic behaviour of swifts (birds he called "apode"; i.e. without feet). Specifically, he wrote: "We see evangelic poverty printed on a small bird, the Apode, which has nothing of the earth, no place to settle or to sit, not on the ground, nor on a branch, or a stone on which to rest ... (but) they are the ladies of the highness, and like neighbours of the stars, they soar up there, always above the clouds where they lack nothing” (authors' own translation; original text in Spanish). However, the author of this noticeable description exaggerated the lack of perches used by the bird, attributing it to an imaginative and nonexistent breeding behaviour: "It has so much poverty, that the female must lay eggs on the back 
of the male".

Owing to this combination of relevant and fantastic facts, it is important to quote or interpret old sources regarding animal behaviour cautiously. Nevertheless, traditional knowledge may constitute a useful source of information. On some occasions it has preceded scientific evidence. For example, the bearded vulture (Gypaetus barbatus) is the only bird in the world whose diet is composed mainly of bones (BROWN 1990), which the animal breaks by dropping them from the air onto the rocks. This behaviour was well known by ancient people where the bird lived; thus, this species surely corresponds to the "ossifrage" (bone-breaker) that is mentioned at the Bible ("they shall not be eaten, they are an abomination: the eagle, and the ossifrage, and the osprey"; Leviticus 11:13), and certainly it is the same bird that was known long ago in Spain as “quebrantahuesos" (bone-breaker). In spite of that, many ornithologists considered that the habit of breaking and eating bones was a legend; for example, MEINERTZHAGeN (1954: 360-363) said he never saw the bird breaking bones in Balochistan, Crete, Pyrenees, Kenya or Arabia, and Geroudet (1965) considered that the breaking of bones should be an unusual activity.

Occasionally, considering old sources of information could have avoided a lot of problems. GARCíA-BELlido (1945) quoted classic Greek and Roman authors who recorded that, in ancient times, the burrowing activity of European rabbits (Oryctolagus cuniculus) was sufficient to undermine the buildings of entire cities in the Baleares Islands (Spain), where the species had been introduced. This did not stop the humancaused spreading of rabbits to all continents except Antarctica, however, with the wellknown disastrous consequences (e.g. ThOMPson \& KING 1994).

On other occasions, traditional knowledge has helped to correct the results of modern orthodox science. For example, censuses by Inuit people of the Hudson Bay in Arctic Canada almost doubled the size of the breeding population of eiders (Somateria mollisima) that was initially estimated by scientists; this is a common and economically important duck in the area (JOHANNES \& NeIS 2007).

Here we will show that some ancient people also recognised a sexual purpose of infanticide perpetrated by male mammals, which is currently an ongoing controversy among scientists.

\section{The infanticide controversy}

In some species of mammals, and also some birds, adults sometimes kill offspring, and particularly males kill offspring that they have not sired (HAUSFATER \& HRDY 1984; VAN SCHAIK \& JANSEN 2000). Over the past four decades there has been 

an acrimonious controversy in the scientific community, especially among anthropologists and primatologists, about the reasons that lead to this behaviour. We will describe the opposite points of view based mainly on Sommer (2000) and ReEs (2009). In a simplistic way, the two alternative explanations for infanticide can be considered as adaptationist (i.e. brought about by selective forces) or non-adaptationist (i.e. an aberrant, pathological pattern of behaviour).

To understand this controversy it is necessary to note that infanticide is a short event very rarely detected in the wild. Thus, early observations were made on captive animals, and many anti-adaptationist researchers attributed them to the "anomalous" conditions of captivity. Thus, they claimed that infanticide was more myth than reality, or it was a fallacy (see Sommer 2000). Besides, during the second half of the twentieth century classical ethologists assumed that in "normal" conditions an instinctive inhibition to kill conspecifics ensured the species' survival (e.g. EIBL-EIBESFELDT 1977). Consequently, the observed cases of infanticide (for example, in different primates, including man, and in lions) were considered to be either the result of an evolutionary or social pathology or caused by stressful conditions (e.g. in captivity, or by the proximity of the human observer in the rare events observed in the wild, or by overcrowding in very dense populations). In these conditions, infanticide was considered to be a product of a general aggressive behaviour of adults, mainly males (e.g. SUSSMAN et al. 1995).

In the 1970s, mainly after HAMILTON (1964) and Wilson (1975), modern behavioural ecology was growing and animals were understood as maximising their individual reproductive success, without considering the good of the species or the group. In this context, infanticide was seen as a targeted aggression benefiting the perpetrators in some way and the result of an evolutionary adaptation. Some adaptationists suggested that the only benefit to infanticidal adults (either males or females) would be to eat the killed offspring (i.e. cannibalism or intraspecific predation). However, most of them, following the bold suggestion of HRDY (1974), thought that infanticide by males was an adaptive product of sexual selection: by killing the offspring of another male, the perpetrator causes the mother to become receptive sooner than otherwise, with a good chance to sire her next litter, thus increasing his fitness. This type of infanticide by males is called sexually selected infanticide (SSI; HRDY \& HAUSFATER 1984).

Although evidence for SSI is accumulating, the controversy about infanticidal behaviour is still alive. According to Sommer (2000), a strong resistance to admitting SSI comes from political and sociological grounds (e.g. it would be dangerous, because it could promote male violence against females). For REES (2009), the main barrier was the difficulty of replicating (hence, demonstrating) field observations. va N ScHAik (2011), however, thinks that the stronger reason for the continuous debate is that traditional anthropologists are reluctant to accept the fundamental continuity between human and nonhuman primates.

In this context, recovering scarce observations of infanticide explained by a sexual purpose that occurred prior to this controversy may have historical interest.

Old references to a sexual purpose of infanticides by male domestic (Felis catus) and wild (Felis sylvestris) cats

Surely the Greek Herodotus (ca 450 B.C.), in his Histories, has been the oldest source to suggest that male domestic cats killed the kittens to obtain sexual access to the deprived females, based on observations in the Egyptian temple of Bubastis. 
According to a translation by D. Grene (quoted by SERPELL 1988), Herodotus wrote: "When females cats gave birth they will no longer frequent the toms and the latter, for all they desire to mate with them, cannot do so. So they contrive the following trick. They steal and carry off the kitten from their mothers and kill them; but although they kill them, they do not eat them. The females deprived from their young and eager to have more, go then, and then only, to the toms; for cats are a breed with a great love for children". Clearly, Herodotus did not think in terms of social pathologies or cannibalistic purposes, but about a "trick" to gain sexual access to females.

The 2500-year-old reference of Herodotus involves a domestic species that lives in societies and breeds communally, where infanticide is more probable (MACDONALD et al. 2010). To our knowledge, the first explanation of infanticide using a sexual aim in a wild species is found in a historic hunting treatise entitled: "Arte de ballestería y montería" (roughly translated "The art of crossbowry and hound hunting”), written by Alonso Martínez del Espinar, who was "Master of the hunt and valet of Their Majesties". It was printed at the Imprenta Real (Royal Printer) of Madrid in 1644 (MARTínez DEL ESPINAR 1644) (a reprint from 1976 has been used for this article). In the 39th chapter of its second book, about the hunting of mammals, under the heading "About the wildcat and its quality" (page 309 in the 1976 reprint), the author properly described the animal as larger and stronger than the domestic cat and grey in colour with some black bands. Regarding its breeding habits he wrote, in the language of those days (authors' own translation; original text in Spanish): "These animals are very lustful, and females like very much to rear kittens; and so, although they suffer great pain when coupling with toms, because their seed is so hot it sets the uterus on fire, yet still the females encourage them with their cries to get pregnant, and after satiating their appetite, they flee from them, and for this reason the males often eat the newborns, because the mother, finding herself without young, then admits males once more". Although Martínez del Espinar could have interpreted the wild cat infanticides as cannibalistic events, as he said the offspring was eaten by the perpetrator, he stressed that the main purpose was a sexual one.

\section{Herodotus, Martínez del Espinar and SSI}

Although the interpretations of both Herodotus and Martínez del Espinar refer to a sexual purpose of infanticide, their descriptions lacked some of the necessary requirements to be considered early descriptions of SSI. For example, two life-history conditions are required to document the existence of SSI: (a) young must be vulnerable, and (b) the loss of the offspring must result in the mother returning shortly to oestrus (VAN NOORDWIJK \& VAN SCHAIK 2000). Implicitly, both authors identified the former in the domestic and wildcat, and explicitly the second one (assuming the need, in multiparous species, of removing the whole litter). In addition, to consider infanticide as sexually selected, it is also necessary to prove that the perpetrator is not the father of the killed offspring (otherwise he would reduce his own fitness), and he gains a high probability of siring the next litter of the victimised female (HRDY \& HAusfater 1984). According to the probable prejudices of their time, old authors recognised that female cats "like very much to rear kittens", but they attributed only sexual appetite to male cats, ignoring the eagerness of paternity (males would copulate to enjoy, whereas females, despite suffering "pain in the uterus", would do it to have descendants). Therefore, they did not consider it relevant whether the infanticidal male could be the father of the killed kittens or that of the next litter of the deprived female. 
It is possible that Martínez del Espinar was inspired by the text of Herodotus, applying the behaviour of the domestic cat described by the Greek to the wildcat. Indeed, both texts have the sexual intention of the perpetrators in common, but they differ in several ways. For instance, Herodotus did not refer to the "pain" and the cries of the females and additionally he considered that killing the offspring is a "trick" by the males, which "seize the kittens, carry them off, and kill them, but do not eat them afterwards" (SERPELl 1988: 154). Martínez del Espinar wrote that males "eat the newborns". In our opinion, the observations are independent and are noteworthy: in the case of Herodotus, because SSI in the domestic cat is infrequent and rarely reported (NAT OLi 1990), and in the case of Martínez del Espinar, because the wildcat is a solitary and very secretive species and, as a consequence, detecting infanticide and its purpose in this species is very difficult.

Several centuries before the seminal prediction by DARWIN (1871) about the evolutionary conflict between sexes, Herodotus and Martínez del Espinar could not know the concepts of parental investment, sexual competition or individual fitness. However, they were able to detect the central point that males killed offspring in order to obtain a mating opportunity with the female deprived of her offspring, and not with the main aim of feeding on them (predatory cannibalism hypothesis; although Martínez del Espinar said the perpetrator ate the offspring, he suggested it did so only to cause the mother to re-enter oestrus) nor because of disturbance (social pathology hypothesis). In this way, they provided surprisingly early support to the SSI hypothesis regarding infanticide by males.

\section{ACKNOWLEDGEMENTS}

M. Delibes-Mateos currently holds a Juan de la Cierva research contract awarded by the Ministerio de Ciencia e Innovación of Spain and the European Social Fund. We are grateful for the comments given by L. Fanini on an earlier draft of this note. An anonymous referee and especially J. Swenson improved a previous version of the manuscript. S. Conradi and A. Cota helped in many ways.

\section{REFERENCES}

BÄCKMAN J. \& AlERstAM T. 2002. Harmonic oscillatory orientation relative to the wind in nocturnal roosting flights of the swift Apus apus. Journal of Experimental Biology 205: 905-910.

BRown C.J. 1990. Food choice and diet of the bearded vulture Gypaetus barbatus in southern Africa. South African Journal of Zoology 25: 169-177.

Bueno-SÁnchez G. 1978. Animales virtuosos y animales científicos. El Basilisco 2: 60-66.

Cotton C.M. 1996. Ethnobotany: principles and applications. London: John Wiley \& Sons.

DARWin C. 1871. The descent of man, and selection in relation to sex. London: John Murray (published by Penguin Classics, London, in 2004).

Eibl-Eibesfeldt I. 1977. Evolution of destructive aggression. Aggressive Behavior 3: 127-144.

GarcíA-Bellido A. 1945. España y los españoles hace dos mil años según la geografía de Strabon. Madrid: Espasa-Calpe.

Geroudet P. 1965. Les rapaces diurnes and nocturnes d’Europe. Neuchâtel: Delachaux et Niestlé.

Hamilton W.D. 1964. The genetical evolution of social behaviour I. Journal of Theoretical Biology 7: $1-16$

Hausfater G. \& Hrdy S.B. (Eds) 1984. Infanticide: comparative and evolutionary perspectives. New York: Aldine. 
Hrdy S.B. 1974. Male-male competition and infanticide among the langurs (Presbytis entellus) of Abu, Rajasthan. Folia Primatologica 22: 19-58.

Hrdy S.B. \& Hausfater G. 1984. Comparative and evolutionary perspectives on infanticide: introduction and overview, pp. xiii-xxxv. In: Hausfater G. \& Hrdy S.B., Eds. Infanticide: comparative and evolutionary perspectives. New York: Aldine.

Johannes R.E., Freeman M.M.R \& Hamilton R.J. 2000. Ignore fishers' knowledge and miss the boat. Fish and Fisheries 1: 257-271.

Johannes R.E. \& Neis B. 2007. The value of anecdote, pp. 41-58. In: UNESCO, Ed. Fishers' knowledge in fisheries science and management. Paris: UNESCO.

LACK D. 1956. Swifts in a tower. London: Methuen.

Lescureux N. \& Linnell J.D.C. 2010. Knowledge and perceptions of Macedonian hunters and herders: The influence of species specific ecology of bears, wolves, and lynx. Human Ecology 38: 389-399.

Lestel D., Brunois F. \& Gaunet F. 2006. Etho-ethnology and ethno-ethology. Social Science Information 45: 155-177.

Macdonald D.W., Mosser A. \& Gittleman J.L. 2010. Felid society, pp. 125-160. In: Macdonald D.W. \& Loveridge A.J., Eds. Biology and conservation of wild felids. Oxford: Oxford University Press.

Martínez del Espinar A. 1644. Arte de ballestería y montería. Madrid: Imprenta Real (published by Ediciones Velázquez, Madrid, in 1976).

Meinertzhagen R. 1954. Birds of Arabia. Edinburgh: Oliver and Boyd.

NAT O Li E. 1990. Mating strategies in cats: a comparison of the role and importance of infanticide in domestic cats, Felis catus L., and lions, Panthera leo L. Animal Behaviour 40: 183-186.

NiAmir-Fuller M. 1998. The resilience of pastoral herding in Sahelian Africa, pp. 250-284. In: Berkes F. \& Folke C., Eds. Linking social and ecological systems: management practices and social mechanisms for building resilience. Cambridge: Cambridge University Press.

PinkERTON E. 1998. Integrated management of a temperate montane forest ecosystem through wholistic forestry: a British Columbia example, pp. 363-389. In: Berkes F. \& Folke C., Eds. Linking social and ecological systems: management practices and social mechanisms for building resilience. Cambridge: Cambridge University Press.

Redford K.H. \& SteArman A.M. 1993. Forest-dwelling native Amazonians and the conservation of biodiversity. Conservation Biology 7: 248-255.

REEs A. 2009. The infanticide controversy: primatology and the art of field science. Chicago: University of Chicago Press.

Serpell J.A. 1988. The domestication and history of the cat, pp. 151-158. In: Turner D.C. \& Bateson P., Eds. The domestic cat. The biology of its behaviour. Cambridge: Cambridge University Press.

Sommer V. 2000. The holy wars about infanticide. Which side are you on? And why?, pp. 9-26. In: van Schaik C.P. \& JANSEN C.H., Eds. Infanticide by males and its implications. Cambridge: Cambridge University Press.

Sussman R.W., Cheverud J.M. \& Bartlett T.Q. 1995. Infant killing as an evolutionary strategy: Reality or myth? Evolutionary Anthropology 4: 149-151.

Thompson H.V. \& KIng C.M. 1994. The European rabbit: the history of a successful colonizer. Oxford: Oxford University Press.

VAN NOORDWIJK M.A. \& VAN SCHAIK C.P. 2000. Reproductive patterns in mammals: adaptations against infanticide?, pp. 322-360. In: van Schaik C.P. \& Jansen C.H., Eds. Infanticide by males and its implications. Cambridge: Cambridge University Press.

VAN SCHAIK C.P. 2011. Book review. Infanticide: evolution of a controversy. Ethology 117: $267-269$.

VAN SCHАIK C.P. \& Jansen C.H. (Eds) 2000. Infanticide by males and its implications. Cambridge: Cambridge University Press.

Wilson E.O. 1975. Sociobiology: the new synthesis. Cambridge, MA: Harvard University Press. 
M. DELIBES

Estación Biológica Doñana, CSIC, Avda. Américo Vespucio s/n, Sevilla, Spain (E-mail: Miguel.Delibes@uclm.es).

M.C. BLÁZQUEZ

Centro de Investigaciones Biológicas del Noroeste. Avda. Mar Bermejo 195, 23090 La Paz, B.C.S., México.

M. Delibes-Mateos

Instituto de Investigación en Recursos Cinegéticos, CSIC-UCLM-JCCM, Ronda de Toledo s/n, Ciudad Real, Spain. 